\title{
Immature myeloid-derived suppressor cells: A bridge between inflammation and cancer (Review)
}

\author{
CATERINA MUSOLINO $^{1 *}$, ALESSANDRO ALLEGRA $^{1 *}$, GOVANNI PIOGGIA $^{2}$ and SEBASTIANO GANGEMI ${ }^{3 *}$ \\ ${ }^{1}$ Division of Hematology, Department of General Surgery, Pathological Anatomy and Oncology, University of Messina; \\ ${ }^{2}$ Institute of Clinical Physiology, IFN CNR, Messina Unit; ${ }^{3}$ School and Division of Allergy and Clinical Immunology, \\ Department of Clinical and Experimental Medicine, University Hospital 'G. Martino', Messina, Italy
}

Received January 31, 2015; Accepted April 29, 2015

DOI: $10.3892 /$ or.2016.5291

\begin{abstract}
Chronic inflammation is considered to be one of the hallmarks of tumor initiation and progression. Changes occurring in the microenvironment of progressing tumors resemble the process of chronic inflammation, which begins with ischemia followed by interstitial and cellular edema, appearance of immune cells, growth of blood vessels and tissue repair, and development of inflammatory infiltrates. Moreover, long-term production and accumulation of inflammatory factors lead to local and systemic immunosuppression associated with cancer progression. Of the several mechanisms described to explain this anergy, the accumulation of myeloid cells in the tumor, spleen, and peripheral blood of cancer patients has gained considerable interest. A population of suppressive $\mathrm{CD}_{11} \mathrm{~b}^{+} \mathrm{Gr}-1^{+}$cells has in fact been designated as myeloidderived suppressor cells (MDSCs). MDSCs are a unique category of the myeloid lineage, and they induce the prevention of the development of cytotoxic T lymphocytes (CTLs) in vitro, and the induction of antigen-specific $\mathrm{CD}^{+} \mathrm{T}$-cell tolerance in vivo. Therapeutic approaches directed toward the manipulation of the MDSC population and their function may improve chemoimmune-enhancing therapy for advanced malignancies.
\end{abstract}

\section{Contents}

1. Inflammation and cancer

2. Immature myeloid-derived suppressor cells

3. Inflammation, cancer and immature myeloid-suppressor cells

Correspondence to: Dr Alessandro Allegra, Division of Hematology, Department of General Surgery, Pathological Anatomy and Oncology, University of Messina, Messina, Italy

E-mail: aallegra@unime.it

Contributed equally

Key words: inflammation, cancer, immature myeloid-derived suppressor cells, tumor microenvironment, immune suppression
4. Myeloid-suppresor cells and cancer

5. Myeloid-suppressor cell-induced immunosuppression mechanisms

6. Therapeutical regulation of immature myeloid-derived suppressor cells

7. Conclusion and future perspectives

\section{Inflammation and cancer}

The concept that chronic inflammation facilitates malignant growth was originally proposed by Virchow in the late 1800 's (1). In fact, chronic inflammation is considered to be one of the hallmarks of tumor initiation and progression. Moreover, long-term production and accumulation of inflammatory factors lead to local and systemic immunosuppression associated with cancer progression. Epidemiological studies offer strong support for this concept. For example, the risk of some organ-specific cancers, particularly colorectal cancers, is significantly higher in individuals with chronic inflammation of the target organ (2-4).

Moreover, the correlation between inflammatory mediators, and the clinical outcome of malignant patients has been frequently investigated. Inflammatory components have been shown to induce DNA damage, which contributes to genetic instability and transformed cell proliferation; to promote angiogenesis and thereby enhance tumor growth and invasiveness; and to impair myelopoiesis and hemopoiesis, which cause immune dysfunction and inhibit immune surveillance (5-7). However, the mechanisms by which inflammation mediates its effects are not well understood, and the mechanisms behind this interaction have remained elusive.

Chronic inflammation is clearly involved in shaping the tumor microenvironment and has been referred to as 'host reaction' to the tumor, although it might be more appropriate to think of it as a 'tumor promoting' reaction. Changes occurring in the microenvironment of the progressing tumor resemble the process of chronic inflammation, which begins with ischemia followed by interstitial and cellular edema, appearance of immune cells, growth of blood vessels and tissue repair, and development of inflammatory infiltrates (8).

Among the factors that determine the nature of inflammatory infiltrates found in the tumor microenvironment 
is the hypoxic environment. It is created early in tumor development through activation of hypoxia-responsive genes in tumor cells (9). It favors the influx of those inflammatory cells that depend on the glycolytic pathway for survival, namely, phagocytic macrophages and granulocytes (8). These cells not only survive in the hypoxic environment but contribute to it by hyperproduction of ROS upon local activation (10). Moreover, genetic alterations in oncogenes and tumor-suppressor genes, or epigenetic changes in the tumor that modulate tumor growth and invasion into the surrounding tissue orchestrate the persistence of inflammatory infiltrates. These cellular infiltrates modulate tumor development and progression. The tumor infiltrates vary by size and composition in diverse tumor types and at different stages of tumor development. The tumor programs the cellular infiltrates to sustain a dysregulated inflammation that is hyporesponsive to the tumor. Characterization of the complex interactions among the infiltrates and tumor will aid in defining their role in tumor progression (11).

An initial goal of the inflammatory response is to destroy an invader, which in this case is the tumor. Therefore, the 'immune phase' of tumor-driven inflammation involves a recruitment and influx of antitumor effector cells to the tissue site. However, compared with cellular and humoral responses that are generated in tissues upon infections by exogenous pathogens, those mediated by the tumor are weak. This is probably because most tumor-associated antigens are considered 'self', in contrast to infections with bacteria or viruses which are viewed by the host as 'danger signals' (12).

With respect to anticancer immune responses, many studies have shown that host immune competence in both innate immunity and adaptive immunity is important for cancer prevention, cancer immunosurveillance and the control of cancer progression $(13,14)$. Indeed, in many instances tumors can escape the host immune response (Table I). Many mechanisms of tumor escape operating in the tumor microenvironment have been proposed. Low expression of molecules on tumor cells involved in tumor target cell recognition; absence of costimulation leading to tolerization of $\mathrm{T}$ cells; soluble factors secreted by tumor cells inhibiting $\mathrm{T}$ cell response and regulatory $\mathrm{T}$ cells, and stromal cells may impair immune-cell responses to tumors. Furthermore, tumors can release soluble molecules such as HLA-I (sHLA-I). This, in turn, reduces $\mathrm{T}$ cell-mediated immune response and induces apoptosis of cytolytic effector cells such as natural killer and $\mathrm{CD} 8^{+} \mathrm{T}$ lymphocytes through the engagement of HLA-I receptors such as CD8 and/or activating isoforms of the inhibitory receptor superfamily. The release of soluble ligands for activating receptors, e.g. IL-16-binding proteins and/or MHC class I-related proteins $\mathrm{A}$ and $\mathrm{B}$, the natural ligands of NKG2D, may impair activation, effector cell-mediated recognition and cytolysis of tumor cells. Furthermore, the elimination of antitumor effector cells may be achieved by induction of apoptosis consequent to triggering elicited via activating molecules, such as receptors responsible for natural cytotoxicity, upon their binding with ligands expressed on tumor cells (15).

Immunologic anergy is a common observation in patients and rodents with cancer. This tumor-induced phenomenon may block the potential therapeutic benefit of immunotherapy. In
Table I. Mechanisms of tumor escape.

Low expression of molecules involved in tumor recognition

Soluble factors inhibiting $\mathrm{T}$ cells

Tolerization of T cells

Apoptosis of cytolytic effector cells

Accumulation of myeloid-derived suppressor cells

Table II. Features of myeloid-derived suppressor cells.
Phenotypic characterization

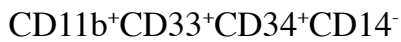
CD $14^{+} \mathrm{CD} 11 b^{+} \mathrm{HLA}^{-} \mathrm{DR}^{\text {low/neg }}$

Ability to suppress T cells

Inhibition of NK cell activity

Inhibition of IL-2 utilization by NK cells

Development of Treg cells

the 1980 's, a new cell population known as natural suppressor cells, distinct from T and NK cells, was described in tumorbearing mice (16). Of the several mechanisms described to explain anergy, the accumulation of myeloid cells in the tumor, spleen, and peripheral blood of tumor-bearing mice and cancer patients has gained considerable interest (17-21).

In fact, recently, a population of suppressive $\mathrm{CD}_{11} \mathrm{~b}^{+} \mathrm{Gr}-1^{+}$cells has been designated as myeloid-derived suppressor cells (MDSCs) (14). MDSCs are a unique category of the myeloid lineage, and they induce the prevention of the development of cytotoxic T lymphocytes (CTL) in vitro (18), and induction of antigen-specific $\mathrm{CD}^{+} \mathrm{T}$-cell tolerance in vivo (16). When cultured in vitro in the presence of appropriate growth factors immature myeloid cells are differentiated into dendritic cells (DCs) or macrophages (22-24).

Generated in bone marrow under the influence of soluble factors produced by tumors, these cells are derived from a mixed population of myeloid cells found at different differentiation stages (25).

\section{Immature myeloid-derived suppressor cells}

Myeloid cells are the most abundant hematopoietic cells in the human body and have diverse functions. Mounting evidence indicates that the tumor microenvironment alters myeloid cells and the concept of MDSCs has emerged $(26,27)$.

MDSCs are a heterogeneous population of immature myeloid cells consisting of myeloid progenitors and precursors of macrophages, granulocytes and DCs (Table II). In mice, MDSCs are identified by antibodies that detect cell surface expression of Gr1 and CD11b. Gr1 includes the macrophage and neutrophil markers Ly6C and Ly6G, respectively, while $\mathrm{CD} 11 \mathrm{~b}$ is characteristic of macrophages. More recently, MDSCs have been subdivided into different subtypes based on their expression of Ly6C and Ly6G. CD11b ${ }^{+}$Ly6 $6{ }^{+}$Ly6 $C^{\text {low }}$ cells with granulocytic-like morphology and multilobed nuclei are called granulocytic MDSCs, whereas CD11b+Ly6G-Ly6C ${ }^{\text {hi }}$ 
cells with monocytic-like morphology are referred to as (Mo)-MDSCs (28).

In cancer patients, MDSCs are identified by surface expression of the myeloid marker CD33 and the lack of expression of markers of mature myeloid and lymphoid cells. They are typically $\mathrm{CD} 11 \mathrm{~b}^{+} \mathrm{CD} 33^{+} \mathrm{CD} 34^{+} \mathrm{CD} 14^{-}$cells that vary in $\mathrm{CD} 15$, CD124, CD66 and MHC class II expression, along with other markers (29). Some authors also use CD31 (also known as platelet/endothelial cell adhesion molecule 1 or ER-MP12) antibodies to further identify these cells (22). CD31 is present on myeloid precursor cells but is downregulated on mature macrophages and neutrophils.

(Mo)-MDSCs with a phenotype of CD14 ${ }^{+} \mathrm{CD} 11 \mathrm{~b}^{+} \mathrm{HLA}$ $\mathrm{DR}^{\text {low/neg }}$ in melanoma patients (30) and a phenotype of

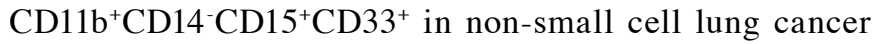
(NSCLC) patients $(31,32)$ have been identified. Due to the variation in MDSC gene expression between different tumor microenvironments, it has been challenging to identify a unique set of markers for human MDSCs. Thus, along with phenotypic characterization, the functional ability of MDSCs to suppress $\mathrm{T}$ cells is the defining hallmark of a MDSC.

Myeloid suppressive cells have also been called 'immature myeloid cells', 'inhibitory macrophages' and 'early myeloid cells' (33). Such immature myeloid cells are present in the bone marrow and spleen of healthy mice, and differentiate into mature myeloid cells under normal conditions (23). The accumulation of $\mathrm{Gr}-1^{+} \mathrm{CD} 11 \mathrm{~b}^{+}$cells in large numbers of tumor-bearing mice probably results from various tumor-derived factors. Release of interleukin (IL)-10 (34), transforming growth factor- $\beta$ (35), IL-6 (36), vascular endothelial growth factor (37), prostanoids (38), prostaglandin E2 (39) and stromal-derived factor- $\alpha$ (40) by tumors has been implicated in preventing the differentiation and maturation of immunoregulatory cells and hampering the induction of antitumor immunity. These cells are also associated with immune suppression during viral infection, transplantation, UV irradiation and cyclophosphamide (CTX) treatment (6).

It has also been shown that the accumulation of MDSCs within either the tumor microenvironment or peripheral blood correlates with a poor prognosis $(41,42)$.

\section{Inflammation, cancer and immature myeloid suppressor cells}

Whereas an acute inflammatory response is vital for the immediate immune defense against pathogens and for the clearance of abnormal self-cells and molecules, a chronic inflammatory response could be detrimental to the host under conditions in which the host is unable to clear the pathogen because of the developing immunosuppression. Thus, the delicate balance between inflammatory response and its extent is critical to a normal or immunosuppressed immune system.

Many studies have shown that inflammatory environments induce the production and the accumulation of MDSCs which are able to block CD4 and CD8- immune responses, and lead to cancer development. Indeed, tumor cells secrete a large variety of cytokines that allow the recruitment of MDSCs in lymphoid organs or peripheral blood and direct their differentiation into suppressor cells (23). That global inflammation controls
MDSC recruitment is best illustrated by observations showing that the reduction of inflammatory potential in $\mathrm{IL}_{-1 \mathrm{R}^{-/}}$mice allows the delay of MDSC accumulation thus reducing tumor and metastatic growth (43).

The IL-1 $\beta$-induced MDSCs described are effective suppressors of $\mathrm{CD}^{+}$and $\mathrm{CD} 8^{+} \mathrm{T}$ lymphocytes. The finding that IL-1 $\beta$ upregulates MDSC accumulation in tumor-bearing mice has led to propose the following causal relationship linking chronic inflammation with tumor progression: as tumor cells proliferate they induce an inflammatory microenvironment consisting of IL-1 $\beta$ and other proinflammatory mediators. The persistence of these mediators causes the accumulation and retention of MDSCs. The MDSCs, in turn, initiate and maintain an immune suppressive state that block immune surveillance, thereby facilitating the survival and proliferation of transformed cells (44).

Jiang et al (45) performed a complex analysis of various inflammatory factors in the peripheral blood of patients suffering from malignant melanoma of different stages. They demonstrated that levels of serum IL-1 $\beta$, IFN- $\gamma$ and CXCL10 were significantly increased in advanced melanoma patients. In addition, these factors were found to be associated with an increased frequency of MDSCs as compared to age- and gender-matched healthy donors. Importantly, advanced melanoma patients with signs of progression displayed markedly elevated concentrations of IL-1 $\beta$ and CXCL10 as compared to patients with stable disease. Moreover, an enrichment of circulating (Mo)-MDSCs was significantly correlated with a decreased progression-free survival of these patients.

Chronic inflammation associated with infectious agents, such as schistosomiasis and Helicobacter pylori, is also thought to predispose to malignancy, and some of these agents are associated with MDSC accumulation $(46,47)$. Collectively, these published observations plus other reported results support the hypothesis that chronic inflammation facilitates tumor growth by inducing MDSCs that downregulate immune surveillance, thereby providing an environment favorable for tumor progression. However, other cytokines beyond IL-1 may play a significant role in the MDSCs in cancer patients.

Kohanbash et al (48) hypothesized a causal role for IL-4R $\alpha$ and myeloid suppressor cells in glioma development. In both mouse de novo gliomas and human glioblastoma cases, IL-4R $\alpha$ was upregulated on glioma-infiltrating myeloid cells but not in the periphery or in the normal brain. Mice genetically deficient for IL-4R $\alpha$ exhibited a slower growth of glioma associated with reduced production in the glioma microenvironment of arginase, a marker of myeloid suppressor cells which is critical for their T cell inhibitory function. Supporting this result, investigations using bone marrow-derived myeloid cells showed that IL-4R $\alpha$ mediates IL-13-induced production of arginase. Furthermore, glioma-derived myeloid cells suppressed $\mathrm{T}$ cell proliferation in an IL-4R $\alpha$-dependent manner, consistent with their identification as MDSCs. Granulocyte-macrophage colony-stimulating factor (GM-CSF) plays a central role in the induction of IL-4R $\alpha$ expression on myeloid cells, and it was found that GM-CSF is upregulated in both human and mouse glioma microenvironments compared with normal brain or peripheral blood samples. Together, these findings establish a GM-CSF-induced mechanism of immunosuppression in 
the glioma microenvironment via upregulation of IL-4R $\alpha$ on MDSCs (48).

TNF is also a key inflammatory cytokine regulating the immune system. TNF is well known to cause inflammatory reactions such as tissue injury in autoimmune diseases mainly by activation of TNF receptor type 1 (TNFR1). Accordingly, blockade of TNF in patients with chronic inflammation and autoimmune diseases is currently being used therapeutically. However, clinical observations in patients after treatment with TNF antagonists indicated that TNF has more complex immune regulatory properties. MDSCs seem to be affected by TNF and TNFR2. TNF-dependent immune suppression was correlated with the development of functional MDSCs in a model of chronic inflammation induced by repetitive application of BCG (49). TNFR2 expression is required for MDSC accumulation during tumor growth and TNFR2 signaling is necessary and sufficient for protection of MDSCs from apoptosis (50).

Other factors may provide the link through which inflammation can contribute to cancer. Proinflammatory S100 proteins promote MDSC accumulation and suppressive activity $(51,52)$. The S100A8 and S100A9 proteins are members of a large family of proteins that includes inflammatory molecules. Heterodimeric S100A8/A9 complexes are calcium-binding proteins that are released by neutrophils, activated monocytes, tumor cells and MDSCs. MDSCs have receptors for S100A8/ A9 complexes and enhance the levels of S100A8/A9 in the tumor microenvironment through an autocrine loop. Antibody blockade of the receptors reduces the number of MDSCs in the tumors and secondary lymphoid organs of tumor-bearing mice. Mice genetically deficient for S100A9 are resistant to challenge with colon carcinoma but become susceptible if MDSCs are adoptively transferred from wild-type mice to S100A9-deficient mice. S100A8/A9 heterodimers mediate these effects through at least two mechanisms: they block the differentiation of myeloid precursors to differentiated DCs and macrophages through a STAT3-dependent mechanism, and they chemoattract MDSCs into the tumor through a $\mathrm{NF}-\kappa \mathrm{B}-$ dependent pathway $(51,52)$.

Toll-like receptors (TLRs) play a major role in the induction of innate and adaptive immune system suppression; repetitive administration of single TLR 2,3, 4 or 9 agonists, which do not exhibit any virulent or immune invasive properties, was sufficient to induce a bystander NK- and T-cell immunosuppression associated with $\zeta$ chain downregulation mediated by MDSCs (53). Vaknin et al (54) identified a 35-amino acid region within the $\zeta$ chain as being responsible for its degradation under TLR-mediated chronic inflammation. Furthermore, they provide evidence that $\zeta$ chain levels could serve as a biomarker for chronic inflammation-dependent immunosuppression.

Downregulation of TCR $\zeta$ chain expression associated with $\mathrm{T}$ cell dysfunction was described in various pathologies, such as advanced cancer (55-61).

The fact that pathologies that differ in their physiology and etiology show decreased $\zeta$ chain expression and exhibit $\mathrm{T}$ cell dysfunction suggests the existence of a common denominator linking these conditions.

Ezernitchi et al (62) demonstrated that under chronic inflammation, secondary lymphatic organs display various immunological milieus; $\zeta$ chain downregulation and $\mathrm{T}$ cell dysfunction are induced in the spleen, peripheral blood and bone marrow, but not in lymph nodes, correlating with elevated levels of $\mathrm{Grl}^{+} \mathrm{Mac}-1^{+} \mathrm{MDSCs}$.

Sustained exposure to Ag that induces chronic inflammatory conditions differentially affects various secondary lymphatic organs; while $\mathrm{T}$ cells in the lymph nodes remain functional and express normal $\zeta$ chain levels, cells in the spleen, peripheral blood and bone marrow are negatively affected and reduce $\zeta$ expression levels and their function is impaired $(63,64)$.

\section{Myeloid-derived suppressor cells and cancer}

Several studies have shown that the number of MDSCs is markedly increased in the peripheral blood of tumor-bearing animals and of patients with cancer, whereas the number of DCs are decreased (65). Upregulation of STAT-3 and secretion of tumor-derived cytokines, such as VEGF, TGF- $\beta$, GM-CSF, IL-10 and prostaglandin, have been shown to arrest differentiation of adenomatous polyposis coli (APC) from their myeloid progenitors and trigger accumulation of MDSCs $(66,67)$.

Expansion of MDSCs should stem from the ability of tumors to secrete myeloid-influencing factors (68). In particular, GM-CSF recruits MDSCs into lymphoid secondary organs and suppresses antigen-specific $\mathrm{T}$ cells when produced by gene-modified cancer cells or when administered exogenously in tumor-bearing mice. This evidence raises the possibility that GM-CSF, a cytokine broadly used in cancer patients for its properties on bone marrow mobilization and immune functions, may promote the expansion of myeloid suppressive components, with negative consequences on tumor antigen-specific immune responses $(69,70)$.

As many as $45 \%$ of tumors have infiltrates that are predominantly of the $\mathrm{GR} 1^{+} \mathrm{CD} 11 \mathrm{~b}^{+}$immature myeloid phenotype. This has been recently reported for murine glioblastoma (71) and colon (72) cancer models (Table III).

A similar condition has been detected in other neoplastic diseases. Melanoma is considered the prototype of immunogenic tumors in humans. However, a role of the immune system in controlling disease may be claimed only in the initial phases, when the presence of $\mathrm{T}$ cells deeply infiltrating tumor lesions favorably impacts prognosis and reduces recurrence risk. With disease progression, immune responses start displaying functional defects and may even turn into mere indicators of tumor burden. In mouse models, these deficiencies are, at least in part, attributed to the accumulation of early differentiated myeloid cells (6).

Similarly, melanoma of the eye's uveal tract is a rare, aggressive cancer with a high mortality rate because of the development of metastatic disease, primarily in the liver, that almost invariably is refractory to therapy. Immune mechanisms have been implicated in uveal melanoma progression, and MDSCs have been identified in the tumors or blood of patients (73).

These cells are significantly and reproducibly increased in melanoma patients compared with healthy donors and are further expanded after administration of an antitumor vaccine that includes GM-CSF. Conversely, melanoma patients do not 
Table III. Cancer models with increased myeloid-derived suppressor cells.

\begin{tabular}{llc}
\hline Cancer & \multicolumn{1}{c}{ Authors } & Reference \\
\hline Melanoma & Serafini et al & $(6)$ \\
& Kusmartsev and Gabrilovich & $(5)$ \\
Glioblastoma & Fujita et al & $(71)$ \\
Colon cancer & Mundy-Bosse et al & $(72)$ \\
Head and neck, & Almand et al & $(79)$ \\
lung and breast & & \\
cancer & & \\
Pancreatic tumors & Tinder et al & \\
\hline
\end{tabular}

present any of the myeloid alterations described in patients affected by other cancer histotypes, which include expansion of lineage-negative cells, myeloid CD34 precursors, and immature cells expressing both monocyte (i.e. CD11b) and granulocyte (i.e. CD15) markers $(74,75)$.

It is therefore certain that the development of metastasis in uveal melanoma is associated with changes in immune effector and regulatory cells consistent with lessening tumor immune surveillance, and these changes are associated with changes in plasma and cellular levels of immune regulatory miRs (76).

Also similar to many human cancers, 4T1 mammary carcinoma induces a profound immune suppression, which can be partially reversed if the primary tumor is removed (77). The finding that $\mathrm{CD}^{-/}$mice, whose primary tumors are surgically removed survive indefinitely despite the presence of metastatic disease, has led to hypothesize that immune surveillance is blocked in wild-type mice. It is now clear that the immune suppression present in mice with 4T1 primary tumors is also mediated by $\mathrm{Grl}^{+} \mathrm{CD} 11 \mathrm{~b}^{+}$MDSCs (78).

An accumulation of phenotypic MDSCs was also found in the peripheral blood of patients with head and neck, lung and breast cancer (79). Finally, the increased proinflammatory milieu correlates with an increased percentage of myeloid suppressor cells in pancreatic tumors and tumor draining lymph nodes (80).

\section{Myeloid-derived suppressor cell-induced immuno- suppression mechanisms}

Abundant evidence exists to indicate that tumor-specific $T$ cells undergo inhibitory regulation and become anergic in tumorbearing hosts (81-83). MDSCs are capable of inhibiting the T-cell proliferative responses induced by alloantigens (84), CD3 ligation (85) or various mitogens (86), and can also inhibit IL-2 utilization by NK cells as well as NK cell activity (87). Moreover, T-cell inactivation by MDSCs in vitro can be mediated through several mechanisms: IFN- $\gamma$-dependent nitric oxide (NO) production (88), Th2-mediated IL-4/IL-13-dependent arginase-1 (Arg-1) synthesis (18), loss of CD3 $\xi$ signaling in $\mathrm{T}$ cells (89) and suppression of the T-cell response through reactive oxygen species (90-92) (Table IV).

MDSC-mediated downregulation of T-cell L-selectin (CD62L) further impairs T-cell activity. CD62L is a plasma
Table IV. Mechanisms of action of myeloid-derived suppressor cells.

Arginase 1 synthesis

Nitric oxide production

Peroxynitrite production

Loss of $\mathrm{CD} 3 \zeta$ signaling in $\mathrm{T}$ cells

Downregulation of $\mathrm{T}$ cell L-selectin

Inhibition of IFN- $\gamma$ and NKG2D expression on NK cells

Pro-angiogenic factors

Induction of matrix metalloproteinases

Cysteine/cystine deprivation

membrane molecule necessary for the homing of naive $\mathrm{T}$ cells to lymph nodes for activation by tumor antigens. MDSCs downregulate CD62L on naive $\mathrm{T}$ cells, which reduce the $\mathrm{T}$ cell capacity to migrate to lymph nodes (93).

MDSCs can also inhibit NK cell activity through membrane-bound TGF- $\beta 1$, resulting in inhibition of IFN- $\gamma$ and NKG2D expression (94). The effect shows a high efficacy since the addition in vitro of only $3 \%$ of MDSCs was able to completely block T-cell proliferation.

As mentioned above, MDSCs induce immunosuppression through two enzymes involved in arginine metabolism: inducible NO synthetase 2, which generates NO, and Arg-1, which depletes L-arginine, generating amino acid starvation for T-cell activation (21).

MDSCs producing high levels of Arg-1 block T-cell function by depleting L-arginine in cancer, chronic infections, and trauma patients. However, the mechanisms that induce Arg-1 in MDSCs in cancer are unknown. Using the 3LL mouse lung carcinoma, Rodriguez et al (95) characterized these mechanisms. Arg-1 expression was independent of T-cell-produced cytokines. Instead, tumor-derived soluble factors resistant to proteases induced and maintained Arg-1 expression in MDSCs.

Moreover, 3LL tumor cells constitutively express cyclooxygenase (COX)-1 and COX-2, and produce high levels of $\mathrm{PGE}_{2}$. Genetic and pharmacological inhibition of COX-2, but not COX-1, blocked Arg-1 induction in vitro and in vivo. Signaling through the $\mathrm{PGE}_{2}$ receptor E-prostanoid 4 expressed in MDSCs induced Arg-1. Furthermore, blocking Arg-1 expression using COX-2 inhibitors elicited lymphocyte-mediated antitumor responses (95).

Peripheral blood mononuclear cells from 123 patients with metastatic renal cell carcinoma (RCC), prior to treatment, were found to have a significantly increased arginase activity. These patients had markedly decreased cytokine production and expressed low levels of T-cell receptor CD3 $\zeta$ chain. Cell separation studies showed that the increased arginase activity was limited to a specific subset of $\mathrm{CD}_{11 b^{+}}, \mathrm{CD} 14^{-}$and $\mathrm{CD} 15^{+}$ cells with a polymorphonuclear granulocyte morphology and markers, instead of macrophages or DCs described in mouse models. Furthermore, these patients had low levels of arginine and high levels of ornithine in plasma. Depletion of the $\mathrm{CD}_{11 \mathrm{~b}^{+}}$and $\mathrm{CD} 14$ - myeloid suppressor cells re-established $\mathrm{T}$-cell proliferation and $\mathrm{CD} 3 \zeta$ chain expression (29). 
How low does arginine have to be to impair T-cell function? Arginine concentrations $<60 \mu \mathrm{mol} / 1$ decreased T-cell proliferation, cytokine production and CD3 $\zeta$ expression in vitro (96). Trauma patients, who experience rapidly increased arginase activity in PBMCs, have profoundly depleted arginine to $0-50 \mu \mathrm{mol} / 1$ (normal levels range $50-150 \mu \mathrm{mol} / 1$ ), resulting in T-cell anergy and loss of CD3 $\zeta(97,98)$. Therefore, arginase-producing cells may decrease arginine levels in the circulation, a phenomenon that may be more profound in the tumor or lymphoid organ microenvironment where these cells are also found.

Unfortunately, replenishment of arginine alone does not seem to be a simple solution. Although arginine replenishment does reestablish $\mathrm{CD} 3 \zeta$ chain expression, it may also stimulate tumor growth $(24,99)$. Therefore, inhibition of the signals that induce Arg-1 in these cells may be an alternative approach.

However, Huang et al (145) proposed a novel mechanism by which tumor-induced MDSCs can suppress tumor-specific T-cell responses. MDSCs mediate the development of Treg cells, which can induce and maintain T-cell tolerance in tumor-bearing hosts. Furthermore, Treg induction and NO-dependent suppressive activity mediated by MDSCs seem to be independent pathways since iNOS-deficient MDSCs lost in vitro suppressive activity but could still induce the development of Tregs both in vitro and in tumor-bearing mice $(24,100)$.

Moreover, it was observed that induced immunosuppression is the consequence of a chronic inflammatory response associated with a dramatic enlargement and disrupted architecture of the spleen attributable to the abnormal accumulation of MDSCs. Immunohistochemical staining of spleen sections from LPS-treated mice revealed that MDSCs tightly border and in some regions invade the T-cell zones. The observed in vivo intimate interaction between MDSCs and $\mathrm{T}$ cells in the affected spleens supports ex vivo data demonstrating that MDSCs confer their immunosuppressive effect on contact or close proximity with $\mathrm{T}$ cells. Co-incubation in the presence of a Transwell was found to abrogate the immunosuppressive effect of the MDSCs $(62,101)$. There is recent data to suggest that these cells also contribute to tumor angiogenesis (102).

MDSCs can directly incorporate into tumor endothelium. They secret many pro-angiogenic factors as well. In addition, they play an essential role in cancer invasion and metastasis through inducing the production of matrix metalloproteinases (MMPs) and chemoattractants and creating a pre-metastatic environment (103).

Moreover, increasing evidence supports the idea that cancer stem cells (CSCs) are responsible for tumorigenesis, resistance to therapies, invasion and metastasis (103). Ye et al (104) hypothesized that CSCs may 'hijack' MDSCs for use as alternative niche cells, leading to the maintenance of stemness and enhanced chemotherapy and radiotherapy resistance. The countermeasure that directly targets MDSCs may be useful against angiogenesis and for preventing cancer from invasion and metastasis.

More recently, peroxynitrite has emerged as a key mediator of T-cell function suppression by MDSCs. Indeed, peroxynitrite is a product of a chemical reaction between NO and the superoxide anion, and is one of the most powerful oxidizers. It induces amino acid nitration and nitrosylation such as cysteine, methionine, tryptophan, and tyrosine. High levels of peroxynitrite have been found in areas where inflammatory cells and MDSCs accumulate. These high levels of peroxynitrite have also been associated with tumor progression in many types of cancer which have been linked to the absence of T-cell responses (105-107).

It appears that the peroxynitrite production by MDSCs during direct contact with T cells leads to TCR and CD8 molecule nitration, changing the specific binding peptide of $\mathrm{T}$ cells and making them intensive to specific antigen stimulation. Also, it has been shown that MDSCs are able to induce TCR/CD3ל complex disruption through tyrosine nitrosylation/nitration, partly through NADPH oxidase 2 activity $(108,109)$.

Finally, two studies identified a new mechanism of suppression based on modulation of local amino acid metabolism and homeostasis. This mechanism, shared with FoxP3 ${ }^{+}$Tregs is called cysteine/cystine deprivation $(110,111)$.

\section{Therapeutical regulation of immature myeloid sup- pressor cells}

Regardless of the mechanism, it has been proposed that elimination of MDSCs will likely be a valuable strategy to lessen tumor-induced immunosuppression, improve antitumor responses and enhance the effects of cancer immunotherapy (112). To date, however, there have been few practical approaches (Table V).

Salvadori et al (113) showed that surgical resection of large tumors led to a very rapid loss of $\mathrm{Gr}-1^{+} / \mathrm{CD} 11 \mathrm{~b}^{+}$splenocytes with restoration of some antitumor immunity. Unfortunately, surgical removal of most metastatic tumors is not feasible.

Earlier experiments demonstrated that depletion of murine $\mathrm{Gr}^{-} 1^{+}$cells significantly improved $\mathrm{CD}^{+} \mathrm{T}$-cell immune response and allowed for eradication of tumors (114), while a more recent study demonstrated that depletion of $\mathrm{Gr}-1^{+}$myeloid cells in vivo prevented tumor recurrence (115).

Depletion of myeloid suppressor cells using anti-Gr-1 antibodies has been suggested. However, this also depletes all the mature granulocytes leading to severe immunosuppression. This depletion is also followed by a rapid rebound of cells (112).

Different approaches that target MDSCs are currently being explored in tumor-bearing hosts. They can be divided based on their ability to control MDSC differentiation into mature DCs and macrophages capable of APC activity, MDSC maturation from precursors, MDSC proliferation, MDSC accumulation, MDSC cytotoxicity, or MDSC function/activation (116).

One approach to therapeutic targeting of MDSCs is the use of agents that promote the differentiation of myeloid cells. Nefedova et al (117) demonstrated that differentiating MDSCs to DCs and macrophages by using all-trans-retinoic acid (ATRA) reduced MDSC numbers and augmented the responses to cancer vaccines. Mirza et al (118) also tested the possibility of pharmacological regulation of myeloid cell differentiation using ATRA. They observed that ATRA dramatically reduced the number of MDSCs. Moreover, ATRA significantly improved the myeloid/lymphoid DC ratio and the ability of mononuclear cells of patients to stimulate allogeneic T cells. This effect was associated with significant 
Table V.Approaches to therapeutic targeting of myeloid-derived suppressor cells.

\begin{tabular}{lc}
\hline Therapy & \multicolumn{1}{c}{ Agent } \\
\hline $\begin{array}{l}\text { Differentiation of myeloid cells } \\
\text { Inhibition of COX-2 enzyme activity }\end{array}$ & $\begin{array}{l}\text { ATRA, IL-4 } \\
\text { Celecoxib } \\
\text { Chemotherapeutic agents }\end{array}$ \\
Inhibition of IL-1 & \\
Sunitinib & \\
Sildenafil & \\
c-kit ligand inhibition & \\
N-acetyl cysteine & \\
Polyamine-blocking therapy &
\end{tabular}

COX, cyclooxygenase; ATRA, all-trans-retinoic acid.

improvement in the tetanus-toxoid (T-T) specific T-cell response (119).

Selective inhibitors of COX-2 enzyme activity have shown chemopreventive activity in carcinogen-induced and transgenic rodent tumor models and clinically for colon cancer. However, the mechanisms by which COX-2 inhibitors reduce carcinogenesis remains controversial. Talmadge et al (119) reported that administration of the selective $\mathrm{COX}-2$ inhibitor, celecoxib, significantly reduced the number of $\mathrm{Grl}^{+} \mathrm{CD} 11 \mathrm{~b}^{+}$ MDSCs during chemoprevention of 1,2-dimethylhydrazine diHCl (1,2-DMH) induction of large intestinal tumors in Swiss mice. The 1,2-DMH induction of large intestinal tumors was associated with a 4-fold increase in MDSCs, and a decrease in splenic T-cell number and function. In addition to delaying tumor induction, reducing tumor number and increasing lymphocyte infiltration of tumors, celecoxib therapy reversed $\mathrm{CD}^{+}{ }^{+} \mathrm{T}$-cell loss, decreased MDSC numbers and increased mRNA levels of nitric oxide synthase-2 (NOS-2) and arginase in the spleen (120).

Chemotherapeutic drug gemcitabine, given at a dose similar to the equivalent dose used in patients, was able to dramatically and specifically reduce the number of MDSCs found in the spleens of animals bearing large tumors with no significant reductions in $\mathrm{CD}^{+}$and $\mathrm{CD}^{+} \mathrm{T}$ cells, and $\mathrm{NK}$, macrophages or B cells. The loss of MDSCs was accompanied by an increase in the antitumor activity of $\mathrm{CD}^{+} \mathrm{T}$ cells and activated NK cells. Combining gemcitabine with cytokine immunogene therapy using IFN- $\beta$ markedly enhanced antitumor efficacy (120).

Although it is clear that gemcitabine was able to eliminate the majority of splenic $\mathrm{Gr}-1^{+} / \mathrm{CD} 11 \mathrm{~b}^{+}$cells in tumor-bearing animals, the mechanism by which this occurred is not known. One possibility was that gemcitabine induced a massive efflux of these cells into the blood and into other organs. Another possibility would be selective killing of the $\mathrm{Gr}-1^{+} / \mathrm{CD} 11 \mathrm{~b}^{+}$ cells. In vitro studies indicate that gemcitabine accelerates the death of $\mathrm{Gr}-1^{+} / \mathrm{CD} 11 \mathrm{~b}^{+}$cells without affecting the numbers of $\mathrm{CD}^{+}$and $\mathrm{CD}^{+} \mathrm{T}$ cells or $\mathrm{B}$ cells. Using flow cytometry, it was possible to show a significantly increased rate of apoptosis in splenocytes at specific time-points after gemcitabine treatment. It is possible that gemcitabine induced differentiation of the $\mathrm{Gr}-1^{+} / \mathrm{CD} 11 \mathrm{~b}^{+}$cells into more mature cells (121).
To note, not all chemotherapeutic agents have this action. The alkylating agent CTX has been included in various chemoimmunotherapy regimens because of its well-known immunostimulatory effects. Paradoxically, CTX can also induce suppressor cells that inhibit immune responses. However, the identity and biologic relevance of these suppressor cells are poorly defined. Jiang et al (124) reported that CTX treatment drives the expansion of inflammatory monocytic myeloid cells $\left(\mathrm{CD} 11 \mathrm{~b}^{+} \mathrm{Ly} 6 \mathrm{C}^{\mathrm{hi}} \mathrm{CCR} 2^{\text {hi }}\right)$ that possess immunosuppressive activities. In mice with advanced lymphoma, adoptive transfer (AT) of tumor-specific $\mathrm{CD}^{+}$ T cells following CTX treatment $(\mathrm{CTX}+\mathrm{CD} 4 \mathrm{AT})$ provoked a robust initial antitumor immune response, but also resulted in enhanced expansion of monocytic myeloid cells. These therapy-induced monocytes inhibited long-term tumor control and allowed subsequent relapse by mediating functional tolerization of antitumor $\mathrm{CD}^{+}$effector cells through the PD-1-PD-L1 axis. PD-1/PD-L1 blockade after CTX+CD4 AT therapy led to persistence of $\mathrm{CD}^{+}$effector cells and durable antitumor effects. In addition to CTX, it was found that melphalan and doxorubicin can also induce (Mo)-MDSCs. These findings reveal a counter-regulatory mechanism elicited by certain chemotherapeutic agents and highlight the importance of overcoming this barrier to prevent late tumor relapse after chemoimmunotherapy (122).

It is well known that proinflammatory IL-1 promotes the development of MDSCs, and IL-1 may play a role in promoting uveal melanoma progression. Inhibiting IL-1 with IL-1R $\alpha$ inhibits tumor growth in vivo but not in vitro. Tumor stroma is modified, MDSCs are reduced and M1 macrophage polarization is increased in vivo (123).

Interleukin-4 (IL-4), a cytokine closely associated with the differentiation of myeloid cells, was expressed locally at the tumor site with its dose and expression time tightly regulated by a Tet-Off system. Early exposure of high-dose IL-4 to the tumor stromal cells effectively prevented the generation of myeloid suppressor cells and led to a T-cell-mediated tumor rejection. However, IL-4 had no effect several days after tumor growth, when myeloid suppressor cells had been generated and $\mathrm{T}$ cells were tolerized. Importantly, co-inoculation of IL-4 receptor (IL-4R)-deficient tumor cells with IL-4R competent, but not IL-4R-deficient myeloid cells led to IL-4-mediated tumor regression in IL-4R-deficient mice, indicating that IL-4 acts directly on myeloid cells (124).

Several studies have evaluated the effect of the TKI sunitinib on MDSCs. The administration of sunitinib, a receptor TKI inhibitor, has been shown to reduce the frequency of MDSCs and reverse T-cell immune suppression in the peripheral blood of patients with metastatic RCC and in several murine tumor models. However, sunitinib has a variable impact in reducing MDSCs and restoring T-cell activity in the tumor microenvironment, which seems to be tumor-dependent $(125,126)$.

Pan et al (127) demonstrated that the expression of c-kit ligand [stem cell factor (SCF)] by tumor cells may be important for MDSC accumulation in tumor-bearing mice, and that blocking the c-kit ligand-c-kit receptor interaction can reverse MDSC-mediated immune suppression. Mice bearing tumor cells with SCF siRNA knockdown exhibited significantly reduced MDSC expansion and restored proliferative responses of tumor-infiltrating $\mathrm{T}$ cells. The blockade of SCF receptor 
(c-kit)-SCF interaction by anti-c-kit antibodies prevented tumor-specific T-cell anergy, Treg development and tumor angiogenesis (127).

$\mathrm{N}$-acetylcysteine (NAC) has been proposed as an antitumorigenic agent due to its ability to reduce the oxidative stress that promotes genetic instability (128). NAC may have the additional benefit of facilitating T-cell activation by increasing extracellular pools of cysteine in the presence of high levels of MDSCs in cancer patients. Although NAC targets the cysteine pathway of MDSC-mediated T-cell suppression, MDSC production of arginase and NO can still maintain the suppressive effects of MDSCs. However, administration of NAC, in combination with other agents that block additional MDSC suppressive pathways (Arg-1 and NO), may be more effective at inhibiting MDSCs and facilitate the treatment of cancers (128).

Polyamine elevation in cancer, a common metabolic aberration in aggressive lesions, contributes significantly to tumor immunosuppression, and a polyamine depletion strategy can exert antitumor effects that may also promote immunity. A polyamine-blocking therapy (PBT) that combines the well-characterized ornithine decarboxylase (ODC) inhibitor difluoromethylornithine (DFMO) with AMXT 1501, a novel inhibitor of the polyamine transport system, blocked tumor growth in immunocompetent mice but not in athymic nude mice lacking $\mathrm{T}$ cells. PBT had little effect on the proliferation of epithelial tumor cells, but it increased the number of apoptotic cells. Analysis of $\mathrm{CD}^{4} 5^{+}$tumor immune infiltrates revealed that $\mathrm{PBT}$ decreased levels of $\mathrm{Gr}-1^{+} \mathrm{CD} 11 \mathrm{~b}^{+}$myeloid suppressor cells and increased $\mathrm{CD}^{+} \mathrm{T}$ cells. Strikingly, in a model of neoadjuvant chemotherapy, mice administered with PBT one week before surgical resection of engrafted mammary tumors exhibited resistance to subsequent tumor rechallenge (129).

Polyphenon E reduced the number of tumor-infiltrating myeloid cells, and inhibited the development of spontaneous neuroblastomas in TH-MYCN transgenic mice. In therapeutic models of neuroblastoma in $\mathrm{A} / \mathrm{J}$, but not in immunodeficient NOD/SCID mice, Polyphenon E inhibited tumor growth by acting on MDSCs and CD8 T cells. In vitro, Polyphenon E impaired the development and motility of MDSCs and promoted differentiation to more neutrophilic forms through the $67-\mathrm{kDa}$ laminin receptor signaling and induction of GM-CSF. The proliferation of $\mathrm{T}$ cells infiltrating a patient metastasis was reactivated by Polyphenon E (130).

Phosphodiesterase-5 (PDE5) inhibitors (sildenafil) are agents currently in clinical use for nonmalignant conditions. Sildenafil treatment decreased the suppressive activity of MDSCs by downregulating Arg-1 and inducible NOS-2 expression. Sildenafil restored in vitro $\mathrm{T}$ cell proliferation of PBMCs from multiple myeloma patients. By reverting MDSC suppression, sildenafil enhanced intratumoral $\mathrm{T}$ cell infiltration and reduced tumor outgrowth in vivo (131).

Treatment with aminobiphosphonate was shown to reduce MDSC expansion in tumors and peripheral blood by inhibiting MMP-9 (132). Since VEGF has been shown to block DC differentiation and maturation in preclinical models, high levels of VEGF in cancer patients may induce an accumulation of immature and functionally impaired DCs contributing to tumor escape from immunosurveillance. It was hypothesized that tumor-derived VEGF might exert its inhibitory effect at the stage of immature HLA-DR-MDC precursors within the MDSC fraction blocking their development into pMDCs, while simultaneously skewing their differentiation towards a newly identified population of myeloid CD14+HLA-DR ${ }^{\text {neg/low }}$ suppressor cells with immunosuppressive traits (132).

VEGFR/PDGFR inhibitors have demonstrated clinical efficacy as a first-line therapeutic agent in the setting of a renal cell carcinoma, via mechanisms that include the suppression of angiogenesis and inhibition of MDSC and Treg function in vivo (134-142).

However, the therapeutic benefits of agents that regulate MDSCs are only evident when they are combined with immune therapy and not when they are administered alone. Thus, cancer immune therapy offers an attractive therapeutic addition, delivering treatment with high specificity, low toxicity and prolonged activity.

\section{Conclusion and future perspectives}

Priming of the adaptive immune response occurs during the early stage of tumor growth and results in development of $\mathrm{CD}^{+} \mathrm{T}$ cells reactive to tumors (1). Despite evident host recognition of tumor antigens, coincident with or immediately subsequent to T-cell priming, the antitumor immune response is inadequate to eliminate the tumor and is eventually dampened, thereby leading to tumor escape. Understanding how cancer growth affects the antitumor immune response and discovering how escape from antitumor immunity can be reversed are major goals in tumor immunology (143).

Tumors escape immune attack by a variety of mechanisms, including differentiation and recruitment of immunosuppres-

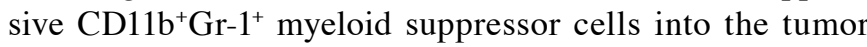
microenvironment.

However, despite numerous studies on the subject, we are still far from a full understanding of the mechanisms regulated by these cells and even on the action that these cells may have in specific conditions. New data continuously accumulate and even on their exact identification confusion and doubt exist.

Hart et al (144) used the chemokine receptor CX3CR1 to identify distinct populations within the monocyte, macrophage and DC lineages. They found a population that is functionally distinct from the CX3CR1-positive cellular subsets within the $\mathrm{CD}_{1} 1 \mathrm{~b}^{+}$cellular compartment of ascites from ovarian tumor-bearing mice. They functionally identified CX3CR1 ${ }^{-}$ cells as myeloid suppressor cells and as a cellular subset with pathological specificity. Importantly, the CX3CR1- cells exhibit early IL-10 production in the ovarian tumor microenvironment, which was shown to be critically tied to suppression and additional MDSC accumulation.

Huang et al (145) identified a more specific population within Percoll fraction 2 MDSCs that expresses the myeloid markers Gr-1, CD115 (M-CSF receptor) and F4/80, which has much stronger suppressive activity compared with the classic Gr- $1^{+} \mathrm{CD} 11 b^{+}$MDSCs. Although Gr- $1^{+}$immature myeloid cells from the spleens of tumor-bearing mice have been shown to suppress the proliferation of $\mathrm{CD}^{+}$and $\mathrm{CD}^{+} \mathrm{T}$ cells, the sorted Gr-1 single positive cells of Percoll fraction 2 did not suppress HA-mediated proliferation of CD4. 
On the other hand, Tomihara et al (146) showed that $\mathrm{CD} 11 \mathrm{~b}^{+} \mathrm{Gr}-1^{+}$cells found in ascites of epithelial ovarian cancer-bearing mice at advanced stages of disease were immunostimulatory rather than being immunosuppressive. Immunostimulatory $\mathrm{CD} 11 \mathrm{~b}^{+} \mathrm{Gr}-1^{+}$cells can strongly cross-prime, augmenting the proliferation of functional CTLs via signaling through the expression of costimulatory molecule CD80. Adoptive transfer of these immunostimulatory $\mathrm{CD} 11 \mathrm{~b}^{+} \mathrm{Gr}-1^{+}$cells from ascites of ovarian cancer-bearing mice resulted in the significant regression of s.c. tumors even without being pulsed with exogenous tumor Ag prior to AT.

Several observations of nonsuppressive CD11 $\mathrm{b}^{+} \mathrm{Gr}-1^{+}$cells have actually been reported. For example, activated NKT cells have been shown to induce the conversion of MDSCs to immunogenic APCs, presumably by producing soluble factors from activated NKT cells (147). It has also been shown that $\mathrm{Gr}-1^{+} \mathrm{CD} 11 \mathrm{~b}^{+} \mathrm{F} 4 / 80^{+}$macrophage-like cells suppressed T-cell proliferation, but that $\mathrm{Gr}-1^{+} \mathrm{CD} 11 \mathrm{~b}^{+} \mathrm{F} 4 / 80^{-}$neutrophillike cells were not suppressive in a tumor-bearing mouse model (148). Even suppressive $\mathrm{Gr}-1^{+} \mathrm{CD} 11 \mathrm{~b}^{+} \mathrm{F} 4 / 80^{+}$cells induced NK cell-mediated killing in an RMA-S tumor, whereas anti-Gr-1 mAb administration resulted in enhanced tumor growth. Interestingly, recent publications have demonstrated a clear distinction between the immunologic function of $\mathrm{CD} 11 \mathrm{~b}^{+} \mathrm{Gr}-1^{\text {high }}$ cells and $\mathrm{CD} 11 \mathrm{~b}^{+} \mathrm{Gr}-\mathrm{1}^{\text {int/low }}$ cells isolated from spleens of either naive or tumor-bearing mice (149-151). In these cases, $\mathrm{CD} 11 \mathrm{~b}^{+} \mathrm{Gr}-1^{\text {high }}$ cells exhibited much less immunosuppressive function compared with $\mathrm{CD} 11 \mathrm{~b}^{+} \mathrm{Gr}-1^{\text {int/low }}$ cells. Immunostimulatory $\mathrm{CD} 11 \mathrm{~b}^{+} \mathrm{Gr}-1^{+}$cells generated in ID8/ascites were morphologically similar to $\mathrm{CD} 11 \mathrm{~b}^{+} \mathrm{Gr}-\mathrm{-}^{\text {high }}$ cells, but only immunostimulatory $\mathrm{CD}_{1} 1 \mathrm{~b}^{+} \mathrm{Gr}-\mathrm{1}^{+}$cells exhibited strong immunostimulatory properties with cross-priming. Furthermore, the expression pattern of surface molecules and a shift in side scatter in flow cytometry were dissimilar. Therefore, immunostimulatory $\mathrm{CD} 11 \mathrm{~b}^{+} \mathrm{Gr}-1^{+}$cells may be a distinct population from $\mathrm{CD} 11 \mathrm{~b}^{+} \mathrm{Gr}-1^{\text {high }}$ cells.

The biological significance and clinical relevance of these cells remain to be determined. Finally, the discovery of new mediators of the action of MDSCs creates new possible intervention methods to eliminate the immune anergy that accompanies cancer.

SHIP is a $145-\mathrm{kDa}$ protein that possesses 5 'phosphatase activity, and thus can hydrolyze the 5'phosphate on phosphatidylinositol-3,4,5-trisphosphate and inositol 1,3,4,5-tetrakisphosphate, which are products of PI3K activity (152). SHIP is primarily expressed in hemopoietic cells, but it can also be expressed in mouse embryonic fibroblasts. The SHIP locus also encodes a stem cell-specific isoform called s-SHIP that lacks the Src homology 2 domain and is expressed by pluripotent and tissue-specific stem cells. SHIP's role in signal transduction allows it to regulate cell survival, proliferation, apoptosis, and homeostasis of certain hemopoietic cell types, as well as primitive stem cell populations. Analysis of SHIP-deficient mice revealed that this protein also has a prominent role in the immune system. Significant pathologies have been observed in $\mathrm{SHIP}^{-/}$mice, including splenomegaly and an infiltration of myeloid cells into the lungs that contributes to their reduced life span $(153,154)$.

The induction of SHIP deficiency in adult mice leads to a rapid and significant expansion of MDSCs in peripheral lymphoid tissues. Consistent with expansion of MDSCs, splenocytes and lymph node cells from adult mice with induced SHIP deficiency are significantly compromised in their ability to prime allogeneic T-cell responses. These results demonstrated that SHIP regulates homeostatic signals for these immunoregulatory cells in adult physiology (155).

Similarly, TIMP-2 is a multifunctional protein, secreted into the extracellular matrix. TIMP-2 is a negative regulator of MDSCs with important implications for the immunotherapy and/or anti-angiogenic treatment of NSCLC (156). But unexpected new fields of study seem to continually open up to researchers.

The effectiveness of attenuated Salmonella in inhibiting tumor growth has been demonstrated in many therapeutic models, but the precise mechanisms remain incompletely understood. Kaimala et al (157) showed that the antitumor capacity of Salmonella depends on a functional MyD88-TLR pathway and is independent of adaptive immune responses. Since MDSCs play a critical role in tumor growth, they investigated the consequences of Salmonella treatment on myeloid cell recruitment, phenotypic characteristics, and functional activation in spleen and tumor tissue of B16 and F1 melanoma-bearing mice. Salmonella treatment led to increased accumulation of splenic and intratumoral $\mathrm{CD} 11 \mathrm{~b}^{+} \mathrm{Gr}-1^{+}$ myeloid cells, exhibiting significantly increased expression of various activation markers such as MHC class II, costimulatory molecules, and Sca-1/Ly6A proteins. Gene expression analysis showed that Salmonella treatment induced expression of iNOS, Arg- 1 and IFN- $\gamma$ in the spleen, but downregulated IL- 4 and TGF- $\beta$. Within the tumor, expression of iNOS, IFN- $\gamma$ and S100A9 was markedly increased, but Arg-1, IL-4, TGF- $\beta$ and VEGF were inhibited. Functionally, splenic CD11b ${ }^{+}$cells maintained their suppressive capacity following Salmonella treatment, but intratumoral myeloid cells had significantly reduced suppressive capacity. Their findings demonstrated that administration of attenuated Salmonella leads to phenotypic and functional maturation of intratumoral myeloid cells making them less suppressive and hence enhancing the host's antitumor immune response (157).

In conclusion, MSDCs are metabolically plastic, evidenced by their ability to differentiate under the influence of select cytokines and differentiation factors into more mature cell types both in vitro and in vivo. Significantly, forced maturation of MDSCs in vivo was associated with enhancement of chemotherapy efficacy, suggesting a potentially novel therapeutic strategy. Therapeutic approaches directed toward the manipulation of the MDSC population and their function may improve immune-enhancing therapy for advanced malignancies.

\section{References}

1. Balkwill $\mathrm{F}$ and Mantovani A: Inflammation and cancer: back to Virchow? Lancet 357: 539-545, 2001.

2. Kuper H, Adami HO and Trichopoulos D: Infections as a major preventable cause of human cancer. J Intern Med 248: 171-183, 2000.

3. Shacter E and Weitzman SA: Chronic inflammation and cancer. Oncology (Williston Park) 16: 217-232, 2002.

4. Coussens LM and Werb Z: Inflammation and cancer. Nature 420: 860-867, 2002.

5. Kusmartsev S and Gabrilovich DI: Immature myeloid cells and cancer-associated immune suppression. Cancer Immunol Immunother 51: 293-298, 2002. 
6. Serafini P, De Santo C, Marigo I, Cingarlini S, Dolcetti L, Gallina G, Zanovello P and Bronte V: Derangement of immune responses by myeloid suppressor cells. Cancer Immunol Immunother 53: 64-72, 2004.

7. Vakkila $J$ and Lotze MT: Inflammation and necrosis promote tumour growth. Nat Rev Immunol 4: 641-648, 2004.

8. Aller MA, Arias JL, Nava MP and Arias J: Posttraumatic inflammation is a complex response based on the pathological expression of the nervous, immune, and endocrine functional systems. Exp Biol Med 229: 170-181, 2004

9. Denko NC, Fontana LA, Hudson KM, Sutphin PD, Raychaudhuri S, Altman R and Giaccia AJ: Investigating hypoxic tumor physiology through gene expression patterns. Oncogene 22: 5907-5914, 2003.

10. Whiteside TL: The tumor microenvironment and its role in promoting tumor growth. Oncogene 27: 5904-5912, 2008.

11. Srivastava MK, Andersson $\AA$, Zhu L, Harris-White M, Lee JM, Dubinett $S$ and Sharma S: Myeloid suppressor cells and immune modulation in lung cancer. Immunotherapy 4: 291-304, 2012.

12. Gallucci S and Matzinger P: Danger signals: SOS to the immune system. Curr Opin Immunol 13: 114-119, 2001.

13. Whiteside TL: Immune suppression in cancer: effects on immune cells, mechanisms and future therapeutic intervention. Semin Cancer Biol 16: 3-15, 2006.

14. Smyth MJ, Dunn GP and Schreiber RD: Cancer immunosurveillance and immunoediting: The roles of immunity in suppressing tumor development and shaping tumor immunogenicity. Adv Immunol 90: 1-50, 2006.

15. Poggi A and Zocchi MR: Mechanisms of tumor escape: role of tumor microenvironment in inducing apoptosis of cytolytic effector cells. Arch Immunol Ther Exp 54: 323-333, 2006.

16. Strober S: Natural suppressor (NS) cells, neonatal tolerance, and total lymphoid irradiation: exploring obscure relationships. Annu Rev Immunol 2: 219-237, 1984.

17. Gabrilovich DI, Velders MP, Sotomayor EM and Kast WM Mechanism of immune dysfunction in cancer mediated by immature Gr-1+ ${ }^{+}$myeloid cells. J Immunol 166: 5398-5406, 2001.

18. Bronte V, Serafini P, De Santo C, Marigo I, Tosello V, Mazzoni A Segal DM, Staib C, Lowel M, Sutter G, et al: IL-4-induced arginase 1 suppresses alloreactive $\mathrm{T}$ cells in tumor-bearing mice. J Immunol 170: 270-278, 2003.

19. Liu Y, Van Ginderachter JA, Brys L, De Baetselier P, Raes G and Geldhof AB: Nitric oxide-independent CTL suppression during tumor progression: association with arginase-producing (M2) myeloid cells. J Immunol 170: 5064-5074, 2003

20. Mazzoni A, Bronte V, Visintin A, Spitzer JH, Apolloni E, Serafini P, Zanovello P and Segal DM: Myeloid suppressor lines inhibit $\mathrm{T}$ cell responses by an NO-dependent mechanism. J Immunol 168: 689-695, 2002.

21. Rodriguez PC, Quiceno DG, Zabaleta J, Ortiz B, Zea AH, Piazuelo MB, Delgado A, Correa P, Brayer J, Sotomayor EM et al: Arginase I production in the tumor microenvironment by mature myeloid cells inhibits T-cell receptor expression and antigen-specific T-cell responses. Cancer Res 64: 5839-5849, 2004.

22. Bronte V, Apolloni E, Cabrelle A, Ronca R, Serafini P, Zamboni P, Restifo NP and Zanovello P: Identification of a $\mathrm{CD} 11 \mathrm{~b}(+) / \mathrm{Gr}-1(+) / \mathrm{CD} 31(+)$ myeloid progenitor capable of activating or suppressing CD8(+) T cells. Blood 96: 3838-3846, 2000 .

23. Kusmartsev S and Gabrilovich DI: Inhibition of myeloid cell differentiation in cancer: the role of reactive oxygen species. J Leukoc Biol 74: 186-196, 2003.

24. Li Q, Pan PY, Gu P, Xu D and Chen SH: Role of immature myeloid Gr- $1^{+}$cells in the development of antitumor immunity. Cancer Res 64: 1130-1139, 2004.

25. Gabrilovich DI: Molecular mechanisms and therapeutic reversal of immune suppression in cancer. Curr Cancer Drug Targets 7: 1 , 2007.

26. Youn JI, Nagaraj S, Collazo M and Gabrilovich DI: Subsets of myeloid-derived suppressor cells in tumor-bearing mice. J Immunol 181: 5791-5802, 2008.

27. Youn JI and Gabrilovich DI: The biology of myeloid-derived suppressor cells: the blessing and the curse of morphological and functional heterogeneity. Eur J Immunol 40: 2969-2975, 2010.

28. Condamine T and Gabrilovich DI: Molecular mechanisms regulating myeloid-derived suppressor cell differentiation and function. Trends Immunol 32: 19-25, 2011.
29. Zea AH, Rodriguez PC, Atkins MB, Hernandez C, Signoretti S, Zabaleta J, McDermott D, Quiceno D, Youmans A, O'Neill A, et al: Arginase-producing myeloid suppressor cells in renal cell carcinoma patients: a mechanism of tumor evasion. Cancer Res 65: 3044-3048, 2005.

30. Poschke I, Mougiakakos D, Hansson J, Masucci GV and Kiessling R: Immature immunosuppressive CD14 ${ }^{+} L^{-} \mathrm{DR}^{-1 / \text { ow }}$ cells in melanoma patients are Stat $3^{\mathrm{hi}}$ and overexpress CD80, CD83, and DC-Sign. Cancer Res 70: 4335-4345, 2010.

31. Srivastava MK, Bosch JJ, Thompson JA, Ksander BR Edelman MJ and Ostrand-Rosenberg S: Lung cancer patients CD4(+) T cells are activated in vitro by MHC II cell-based vaccines despite the presence of myeloid-derived suppressor cells. Cancer Immunol Immunother 57: 1493-1504, 2008.

32. Almand B, Clark JI, Nikitina E, van Beynen J, English NR, Knight SC,Carbone DP and Gabrilovich DI: Increased production of immature myeloid cells in cancer patients: a mechanism of immunosuppression in cancer. J Immunol 166: 678-689, 2001.

33. Peláez B, Campillo JA, López-Asenjo JA and Subiza JL: Cyclophosphamide induces the development of early myeloid cells suppressing tumor cell growth by a nitric oxide-dependent mechanism. J Immunol 166: 6608-6615, 2001.

34. Goddard S, Youster J, Morgan E and Adams DH: Interleukin-10 secretion differentiates dendritic cells from human liver and skin. Am J Pathol 164: 511-519, 2004.

35 . Halliday GM and Le S: Transforming growth factor- $\beta$ produced by progressor tumors inhibits, while IL-10 produced by regressor tumors enhances, Langerhans cell migration from skin. Int Immunol 13: 1147-1154, 2001

36. Chomarat P, Banchereau J, Davoust J and Palucka AK: IL-6 switches the differentiation of monocytes from dendritic cells to macrophages. Nat Immunol 1: 510-514, 2000.

37. Gabrilovich DI, Chen HL, Girgis KR, Cunningham HT, Meny GM, Nadaf S, Kavanaugh D and Carbone DP: Production of vascular endothelial growth factor by human tumors inhibits the functional maturation of dendritic cells. Nat Med 2: 1096-1103, 1996

38. Hammad H, de Heer HJ, Soullie T, Hoogsteden HC, Trottein F and Lambrecht BN: Prostaglandin D2 inhibits airway dendritic cell migration and function in steady state conditions by selective activation of the D prostanoid receptor 1. J Immunol 171: 3936-3940, 2003.

39. Jing H, Vassiliou E and Ganea D: Prostaglandin E2 inhibits production of the inflammatory chemokines CCL3 and CCL4 in dendritic cells. J Leukoc Biol 74: 868-879, 2003.

40. Schnurr M, Toy T, Shin A, Hartmann G, Rothenfusser S, Soellner J, Davis ID, Cebon J and Maraskovsky E: Role of adenosine receptors in regulating chemotaxis and cytokine production of plasmacytoid dendritic cells. Blood 103: 1391-1397, 2004.

41. Murdoch C, Muthana M, Coffelt SB and Lewis CE: The role of myeloid cells in the promotion of tumour angiogenesis. Nat Rev Cancer 8: 618-631, 2008.

42. Sica A and Bronte V: Altered macrophage differentiation and immune dysfunction in tumor development. J Clin Invest 117 1155-1166, 2007.

43. Bunt SK, Yang L, Sinha P, Clements VK, Leips J and Ostrand-Rosenberg S: Reduced inflammation in the tumor microenvironment delays the accumulation of myeloid-derived suppressor cells and limits tumor progression. Cancer Res 67: 10019-10026, 2007.

44. Bunt SK, Sinha P, Clements VK, Leips J and Ostrand-Rosenberg S: Inflammation induces myeloid-derived suppressor cells that facilitate tumor progression. J Immunol 176: 284-290, 2006.

45. Jiang H, Gebhardt C, Umansky L, Beckhove P, Schulze TJ, Utikal $\mathbf{J}$ and Umansky V: Elevated chronic inflammatory factors and myeloid-derived suppressor cells indicate poor prognosis in advanced melanoma patients. Int $\mathbf{J}$ Cancer 136: 2352-2360, 2015.

46. Blaser MJ, Chyou PH and Nomura A: Age at establishment of Helicobacter pylori infection and gastric carcinoma, gastric ulcer, and duodenal ulcer risk. Cancer Res 55: 562-565, 1995.

47. Ernst PB and Gold BD: The disease spectrum of Helicobacter pylori: the immunopathogenesis of gastroduodenal ulcer and gastric cancer. Annu Rev Microbiol 54: 615-640, 2000.

48. Kohanbash G, McKaveney K, Sakaki M, Ueda R, Mintz AH, Amankulor N, Fujita M, Ohlfest JR and Okada H: GM-CSF promotes the immunosuppressive activity of glioma-infiltrating myeloid cells through interleukin- 4 receptor- $\alpha$. Cancer Res 73: 6413-6423, 2013 
49. Sade-Feldman M, Kanterman J, Ish-Shalom E, Elnekave M, Horwitz E and Baniyash M: Tumor necrosis factor- $\alpha$ blocks differentiation and enhances suppressive activity of immature myeloid cells during chronic inflammation. Immunity 38 : 541-554, 2013.

50. Polz J, Remke A, Weber S, Schmidt D, Weber-Steffens D, Pietryga-Krieger A, Müller N, Ritter U, Mostböck S and Männel DN: Myeloid suppressor cells require membrane TNFR2 expression for suppressive activity. Immun Inflamm Dis 2: 121-130, 2014

51. Sinha P, Okoro C, Foell D, Freeze HH, Ostrand-Rosenberg S and Srikrishna G: Proinflammatory S100 proteins regulate the accumulation of myeloid-derived suppressor cells. J Immunol 181 4666-4675, 2008.

52. Cheng P, Corzo CA, Luetteke N, Yu B, Nagaraj S, Bui MM, Ortiz M, Nacken W, Sorg C, Vogl T, et al: Inhibition of dendritic cell differentiation and accumulation of myeloid-derived suppressor cells in cancer is regulated by S100A9 protein. J Exp Med 205: 2235-2249, 2008

53. Tsan MF: Toll-like receptors, inflammation and cancer. Semin Cancer Biol 16: 32-37, 2006.

54. Vaknin I, Blinder L, Wang L, Gazit R, Shapira E, Genina O, Pines M, Pikarsky E and Baniyash M: A common pathway mediated through Toll-like receptors leads to T- and natural killer-cell immunosuppression. Blood 111: 1437-1447, 2008.

55. Nakagomi H, Petersson M, Magnusson I, Juhlin C, Matsuda M, Mellstedt H, Taupin JL, Vivier E, Anderson P and Kiessling R: Decreased expression of the signal-transducing $\zeta$ chains in tumor-infiltrating T-cells and NK cells of patients with colorectal carcinoma. Cancer Res 53: 5610-5612, 1993.

56. Matsuda M, Petersson M, Lenkei R, Taupin JL, Magnusson I, Mellstedt H, Anderson P and Kiessling R: Alterations in the signal-transducing molecules of T cells and NK cells in colorectal tumor-infiltrating, gut mucosal and peripheral lymphocytes: correlation with the stage of the disease. Int J Cancer 61: 765-772, 1995.

57. Lai P, Rabinowich H, Crowley-Nowick PA, Bell MC Mantovani G and Whiteside TL: Alterations in expression and function of signal-transducing proteins in tumor-associated $\mathrm{T}$ and natural killer cells in patients with ovarian carcinoma. Clin Cancer Res 2: 161-173, 1996.

58. Kono K, Ressing ME, Brandt RM, Melief CJ, Potkul RK, Andersson B, Petersson M, Kast WM and Kiessling R: Decreased expression of signal-transducing $\zeta$ chain in peripheral T cells and natural killer cells in patients with cervical cancer. Clin Cancer Res 2: 1825-1828, 1996

59. Kurt RA, Urba WJ, Smith JW and Schoof DD: Peripheral T lymphocytes from women with breast cancer exhibit abnorma protein expression of several signaling molecules. Int J Cancer 78 16-20, 1998.

60. Kuss I, Saito T, Johnson JT and Whiteside TL: Clinical significance of decreased $\zeta$ chain expression in peripheral blood lymphocytes of patients with head and neck cancer. Clin Cancer Res 5: 329-334, 1999.

61. Healy CG, Simons JW, Carducci MA, DeWeese TL, Bartkowski M, Tong KP and Bolton WE: Impaired expression and function of signal-transducing $\zeta$ chains in peripheral $\mathrm{T}$ cells and natural killer cells in patients with prostate cancer. Cytometry 32: 109-119, 1998.

62. Ezernitchi AV, Vaknin I, Cohen-Daniel L, Levy O, Manaster E, Halabi A, Pikarsky E, Shapira L and Baniyash M: TCR $\zeta$ downregulation under chronic inflammation is mediated by myeloid suppressor cells differentially distributed between various lymphatic organs. J Immunol 177: 4763-4772, 2006.

63. Baniyash M: TCR $\zeta$-chain downregulation: curtailing an excessive inflammatory immune response. Nat Rev Immunol 4 675-687, 2004

64. Baniyash M: Chronic inflammation, immunosuppression and cancer: new insights and outlook. Semin Cancer Biol 16: 80-88, 2006.

65. Gabrilovich D, Ishida T, Oyama T, Ran S, Kravtsov V, Nadaf S and Carbone DP: Vascular endothelial growth factor inhibits the development of dendritic cells and dramatically affects the differentiation of multiple hematopoietic lineages in vivo. Blood 92: 4150-4166, 1998

66. Wang T, Niu G, Kortylewski M, Burdelya L, Shain K, Zhang S, Bhattacharya R, Gabrilovich D, Heller R, Coppola D, et al: Regulation of the innate and adaptive immune responses by Stat-3 signaling in tumor cells. Nat Med 10: 48-54, 2004
67. Marigo I, Dolcetti L, Serafini P, Zanovello P and Bronte V: Tumor-induced tolerance and immune suppression by myeloid derived suppressor cells. Immunol Rev 222: 162-179, 2008

68. Serafini P, Borrello I and Bronte V: Myeloid suppressor cells in cancer: recruitment, phenotype, properties, and mechanisms of immune suppression. Semin Cancer Biol 16: 53-65, 2006.

69. Bronte V, Chappell DB, Apolloni E, Cabrelle A, Wang M, Hwu P and Restifo NP: Unopposed production of granulocyte-macrophage colony-stimulating factor by tumors inhibits $\mathrm{CD}^{+} \mathrm{T}$ cell responses by dysregulating antigen-presenting cell maturation. J Immunol 162: 5728-5737, 1999.

70. Serafini P, Carbley R, Noonan KA, Tan G, Bronte V and Borrello I: High-dose granulocyte-macrophage colony-stimulating factor-producing vaccines impair the immune response through the recruitment of myeloid suppressor cells. Cancer Res 64: 6337-6343, 2004.

71. Fujita M, Kohanbash G, Fellows-Mayle W, Hamilton RL, Komohara Y, Decker SA, Ohlfest JR and Okada H: COX-2 blockade suppresses gliomagenesis by inhibiting myeloid-derived suppressor cells. Cancer Res 71: 2664-2674, 2011.

72. Mundy-Bosse BL, Lesinski GB, Jaime-Ramirez AC, BenningerK, Khan M, Kuppusamy P, Guenterberg K, Kondadasula SV, Chaudhury AR, La Perle KM, et al: Myeloid-derived suppressor cell inhibition of the IFN response in tumor-bearing mice. Cancer Res 71: 5101-5110, 2011.

73. McKenna KC, Beatty KM, Bilonick RA, Schoenfield L, Lathrop KL and Singh AD: Activated CD $11 b^{+} \mathrm{CD} 15^{+}$granulocytes increase in the blood of patients with uveal melanoma. Invest Ophthalmol Vis Sci 50: 4295-4303, 2009.

74. Young MR, Petruzzelli GJ, Kolesiak K, Achille N, Lathers DM and Gabrilovich DI: Human squamous cell carcinomas of the head and neck chemoattract immune suppressive CD34(+) progenitor cells. Hum Immunol 62: 332-341, 2001.

75. Filipazzi P, Valenti R, Huber V, Pilla L, Canese P, Iero M, Castelli C, Mariani L, Parmiani G and Rivoltini L: Identification of a new subset of myeloid suppressor cells in peripheral blood of melanoma patients with modulation by a granulocytemacrophage colony-stimulation factor-based antitumor vaccine. J Clin Oncol 25: 2546-2553, 2007

76. Achberger S, Aldrich W, Tubbs R, Crabb JW, Singh AD and Triozzi PL: Circulating immune cell and microRNA in patients with uveal melanoma developing metastatic disease. Mol Immunol 58: 182-186, 2014

77. Danna EA, Sinha P, Gilbert M, Clements VK, Pulaski BA and Ostrand-Rosenberg S: Surgical removal of primary tumor reverses tumor-induced immunosuppression despite the presence of metastatic disease. Cancer Res 64: 2205-2211, 2004.

78. Sinha P, Clements VK and Ostrand-Rosenberg S: Reduction of myeloid-derived suppressor cells and induction of M1 macrophages facilitate the rejection of established metastatic disease. J Immunol 174: 636-645, 2005.

79. Almand B, Resser JR, Lindman B, Nadaf S, Clark JI, Kwon ED, Carbone DP and Gabrilovich DI: Clinical significance of defective dendritic cell differentiation in cancer. Clin Cancer Res 6: 1755-1766, 2000.

80. Tinder TL, Subramani DB, Basu GD, Bradley JM, Schettini J, Million A, Skaar T and Mukherjee P: MUC1 enhances tumor progression and contributes toward immunosuppression in a mouse model of spontaneous pancreatic adenocarcinoma. J Immunol 181: 3116-3125, 2008

81. Wolf AM, Wolf D, Steurer M, Gastl G, Gunsilius E and Grubeck-Loebenstein B: Increase of regulatory $\mathrm{T}$ cells in the peripheral blood of cancer patients. Clin Cancer Res 9: 606-612, 2003.

82. Terabe $\mathrm{M}$ and Berzofsky JA: Immunoregulatory $\mathrm{T}$ cells in tumor immunity. Curr Opin Immunol 16: 157-162, 2004.

83. Cuenca A, Cheng F, Wang H, Brayer J, Horna P, Gu L, Bien H, Borrello IM, Levitsky HI and Sotomayor EM: Extra-lymphatic solid tumor growth is not immunologically ignored and results in early induction of antigen-specific T-cell anergy: dominant role of cross-tolerance to tumor antigens. Cancer Res 63: 9007-9015, 2003.

84. Schmidt-Wolf IG, Dejbakhsh-Jones S, Ginzton N, Greenberg P and Strober S: T-cell subsets and suppressor cells in human bone marrow. Blood 80: 3242-3250, 1992.

85. Young MR, Wright MA, Matthews JP, Malik I and Prechel M: Suppression of T cell proliferation by tumor-induced granulocyte-macrophage progenitor cells producing transforming growth factor- $\beta$ and nitric oxide. J Immunol 156: 1916-1922, 1996. 
86. Angulo I, Rodríguez R, García B, Medina M, Navarro J and Subiza JL: Involvement of nitric oxide in bone marrow-derived natural suppressor activity. Its dependence on IFN- $\gamma$. J Immunol 155: 15-26, 1995.

87.Brooks JC and Hoskin DW: The inhibitory effect of cyclophosphamide-induced MAC-1 ${ }^{+}$natural suppressor cells on IL-2 and IL-4 utilization in MLR. Transplantation 58 1096-1103, 1994

88. Kusmartsev SA, Li Y and Chen SH: Gr- $1^{+}$myeloid cells derived from tumor-bearing mice inhibit primary $\mathrm{T}$ cell activation induced through CD3/CD28 costimulation. J Immunol 165: 779-785, 2000.

89. Rodriguez PC, Zea AH, DeSalvo J, Culotta KS, Zabaleta J, Quiceno DG, Ochoa JB and Ochoa AC: L-arginine consumption by macrophages modulates the expression of $\mathrm{CD} 3 \zeta$ chain in T lymphocytes. J Immunol 171: 1232-1239, 2003.

90. Bronte V, Serafini P, Mazzoni A, Segal DM and Zanovello P. $\mathrm{L}$-arginine metabolism in myeloid cells controls T-lymphocyte functions. Trends Immunol 24: 302-306, 2003.

91. Kusmartsev S, Nefedova Y, Yoder D and Gabrilovich DI Antigen-specific inhibition of $\mathrm{CD} 8^{+} \mathrm{T}$ cell response by immature myeloid cells in cancer is mediated by reactive oxygen species. J Immunol 172: 989-999, 2004.

92. Schmielau J and Finn OJ: Activated granulocytes and granulocyte-derived hydrogen peroxide are the underlying mechanism of suppression of T-cell function in advanced cancer patients. Cancer Res 61: 4756-4760, 2001.

93. Hanson EM, Clements VK, Sinha P, Ilkovitch D and Ostrand-Rosenberg S: Myeloid-derived suppressor cells down-regulate $\mathrm{L}$-selectin expression on $\mathrm{CD} 4^{+}$and $\mathrm{CD} 8^{+} \mathrm{T}$ cells J Immunol 183: 937-944, 2009.

94.Li H, Han Y, Guo Q, Zhang M and Cao X: Cancer-expanded myeloid-derived suppressor cells induce anergy of NK cells through membrane-bound TGF- $\beta$ 1. J Immunol 182: 240-249, 2009.

95.Rodriguez PC, Hernandez CP, Quiceno D, Dubinett SM, Zabaleta J, Ochoa JB, Gilbert J and Ochoa AC: Arginase I in myeloid suppressor cells is induced by COX-2 in lung carcinoma. J Exp Med 202: 931-939, 2005.

96. Taheri F, Ochoa JB, Faghiri Z, Culotta K, Park HJ, Lan MS, Zea $\mathrm{AH}$ and Ochoa AC: 1-Arginine regulates the expression of the T-cell receptor $\zeta$ chain $(\mathrm{CD} 3 \zeta)$ in Jurkat cells. Clin Cancer Res 7: 958-965, 2001

97. Bernard AC, Mistry SK, Morris SM Jr, O'Brien WE, Tsuei BJ, Maley ME, Shirley LA, Kearney PA, Boulanger BR and Ochoa JB: Alterations in arginine metabolic enzymes in trauma Shock 15: 215-219, 2001.

98. Ichihara F, Kono K, Sekikawa T and Matsumoto Y: Surgical stress induces decreased expression of signal-transducing $\zeta$ molecules in T cells. Eur Surg Res 31: 138-146, 1999.

99.Park KG, Heys SD, Blessing K, Kelly P, McNurlan MA, Eremin $\mathrm{O}$ and Garlick PJ: Stimulation of human breast cancers by dietary L-arginine. Clin Sci 82: 413-417, 1992.

100. Pan PY, Zang Y, Weber K, Meseck ML and Chen SH: OX40 ligation enhances primary and memory cytotoxic $\mathrm{T}$ lymphocyte responses in an immunotherapy for hepatic colon metastases. Mol Ther 6: 528-536, 2002.

101. Makarenkova VP, Bansal V, Matta BM, Perez LA and Ochoa JB: $\mathrm{CD}_{11 \mathrm{~b}} / \mathrm{Gr}-1^{+}$myeloid suppressor cells cause $\mathrm{T}$ cell dysfunction after traumatic stress. J Immunol 176: 2085-2094, 2006.

102. Yang L, DeBusk LM, Fukuda K, Fingleton B, Green-Jarvis B, Shyr Y, Matrisian LM, Carbone DP and Lin PC: Expansion of myeloid immune suppressor $\mathrm{Gr}^{+} \mathrm{CD} 11 \mathrm{~b}^{+}$cells in tumor-bearing host directly promotes tumor angiogenesis. Cancer Cell 6 : 409-421, 2004.

103. Allegra A, Alonci A, Penna G, Innao V, Gerace D, Rotondo F and Musolino C: The cancer stem cell hypothesis: a guide to potential molecular targets. Cancer Invest 32: 470-495, 2014.

104. Ye XZ, Yu SC and Bian XW: Contribution of myeloid-derived suppressor cells to tumor-induced immune suppression, angiogenesis, invasion and metastasis. J Genet Genomics 37: 423-430, 2010.

105. Mantovani G, Macciò A, Madeddu C, Mura L, Gramignano G, Lusso MR, Massa E, Mocci M and Serpe R: Antioxidant agents are effective in inducing lymphocyte progression through cell cycle in advanced cancer patients: assessment of the most important laboratory indexes of cachexia and oxidative stress. J Mol Med 81: 664-673, 2003
106. Szuster-Ciesielska A, Hryciuk-Umer E, Stepulak A, Kupisz K and Kandefer-Szerszeń M: Reactive oxygen species production by blood neutrophils of patients with laryngeal carcinoma and antioxidative enzyme activity in their blood. Acta Oncol 43 252-258, 2004.

107. Bronte V, Kasic T, Gri G, Gallana K, Borsellino G, Marigo I, Battistini L, Iafrate M, Prayer-Galetti T, Pagano F, et al: Boosting antitumor responses of $\mathrm{T}$ lymphocytes infiltrating human prostate cancers. J Exp Med 201: 1257-1268, 2005.

108. Nagaraj S, Gupta K, Pisarev V, Kinarsky L, Sherman S, Kang L, Herber DL, Schneck J and Gabrilovich DI: Altered recognition of antigen is a mechanism of $\mathrm{CD}^{+} \mathrm{T}$ cell tolerance in cancer. Nat Med 13: 828-835, 2007.

109. Nagaraj S, Schrum AG, Cho HI, Celis E and Gabrilovich DI: Mechanism of $\mathrm{T}$ cell tolerance induced by myeloid-derived suppressor cells. J Immunol 184: 3106-3116, 2010.

110. Yan Z, Garg SK and Banerjee R: Regulatory T cells interfere with glutathione metabolism in dendritic cells and T cells. J Biol Chem 285: 41525-41532, 2010

111. Yan Z, Garg SK, Kipnis J and Banerjee R: Extracellular redox modulation by regulatory $\mathrm{T}$ cells. Nat Chem Biol 5: 721-723, 2009.

112. Bronte V, Serafini P, Apolloni E and Zanovello P: Tumor-induced immune dysfunctions caused by myeloid suppressor cells. J Immunother 24: 431-446, 2001.

113. Salvadori S, Martinelli G and Zier K: Resection of solid tumors reverses $\mathrm{T}$ cell defects and restores protective immunity. J Immunol 164: 2214-2220, 2000.

114. Seung LP, Rowley DA, Dubey P and Schreiber H: Synergy between T-cell immunity and inhibition of paracrine stimulation causes tumor rejection. Proc Natl Acad Sci USA 92: 6254-6258, 1995.

115. Terabe M, Matsui S, Park JM, Mamura M, Noben-Trauth N, Donaldson DD, Chen W, Wahl SM, Ledbetter S, Pratt B, et al: Transforming growth factor- $\beta$ production and myeloid cells are an effector mechanism through which CD1d-restricted $\mathrm{T}$ cells block cytotoxic $\mathrm{T}$ lymphocyte-mediated tumor immunosurveillance: abrogation prevents tumor recurrence. J Exp Med 198 1741-1752, 2003

116. Ugel S, Delpozzo F, Desantis G, Papalini F, Simonato F, Sonda N, Zilio S and Bronte V: Therapeutic targeting of myeloid-derived suppressor cells. Curr Opin Pharmacol 9: 470-481, 2009.

117. Nefedova Y, Fishman M, Sherman S, Wang X, Beg AA and Gabrilovich DI: Mechanism of all-trans retinoic acid effect on tumor-associated myeloid-derived suppressor cells. Cancer Res 7: 11021-11028, 2007.

118. Mirza N, Fishman M, Fricke I, Dunn M, Neuger AM, Frost TJ, Lush RM, Antonia S and Gabrilovich DI: All-trans-retinoic acid improves differentiation of myeloid cells and immune response in cancer patients. Cancer Res 66: 9299-9307, 2006

119. Talmadge JE, Hood KC, Zobel LC, Shafer LR, Coles M and Toth B: Chemoprevention by cyclooxygenase- 2 inhibition reduces immature myeloid suppressor cell expansion. Int Immunopharmacol 7: 140-151, 2007.

120. Suzuki E, Kapoor V, Jassar AS, Kaiser LR and Albelda SM: Gemcitabine selectively eliminates splenic $\mathrm{Gr}-1^{+} / \mathrm{CD} 11 \mathrm{~b}^{+}$ myeloid suppressor cells in tumor-bearing animals and enhances antitumor immune activity. Clin Cancer Res 11: 6713-6721, 2005.

121. Hotchkiss RS, Tinsley KW, Hui JJ, Chang KC, Swanson PE, Drewry AM, Buchman TG and Karl IE: p53-dependent and -independent pathways of apoptotic cell death in sepsis. J Immunol 164: 3675-3680, 2000.

122. Ding ZC, Lu X, Yu M, Lemos H, Huang L, Chandler P, Liu K, Walters M, Krasinski A, Mack M, et al: Immunosuppressive myeloid cells induced by chemotherapy attenuate antitumor $\mathrm{CD}^{+} \mathrm{T}$-cell responses through the PD-1-PD-L1 axis. Cancer Res 74: 3441-3453, 2014.

123. Triozzi PL, Aldrich W and Singh A: Effects of interleukin-1 receptor antagonist on tumor stroma in experimental uveal melanoma. Invest Ophthalmol Vis Sci 52: 5529-5535, 2011

124. Jiang J, Wang Z, Li Z, Zhang J, Wang C, Xu X and Qin Z: Early exposure of high-dose interleukin-4 to tumor stroma reverses myeloid cell-mediated T-cell suppression. Gene Ther 17: 991-999, 2010.

125. Ko JS, Zea AH, Rini BI, Ireland JL, Elson P, Cohen P, Golshayan A, Rayman PA, Wood L, Garcia J, et al: Sunitinib mediates reversal of myeloid-derived suppressor cell accumulation in renal cell carcinoma patients. Clin Cancer Res 15 2148-2157, 2009. 
126. Ko JS, Rayman P, Ireland J, Swaidani S, Li G, Bunting KD Rini B, Finke JH and Cohen PA: Direct and differential suppression of myeloid-derived suppressor cell subsets by sunitinib is compartmentally constrained. Cancer Res 70 3526-3536, 2010.

127. Pan PY, Wang GX, Yin B, Ozao J, Ku T, Divino CM and Chen SH: Reversion of immune tolerance in advanced malignancy: modulation of myeloid-derived suppressor cell development by blockade of stem-cell factor function. Blood 111: 219-228, 2008

128. Gao P, Zhang H, Dinavahi R, Li F, Xiang Y, Raman V, Bhujwalla ZM, Felsher DW, Cheng L, Pevsner J, et al: HIF-dependent antitumorigenic effect of antioxidants in vivo. Cancer Cell 12: 230-238, 2007.

129. Hayes CS, Shicora AC, Keough MP, Snook AE, Burns MR and Gilmour SK: Polyamine-blocking therapy reverses immunosuppression in the tumor microenvironment. Cancer Immunol Res 2: 274-285, 2014

130. Santilli G, Piotrowska I, Cantilena S, Chayka O, D'Alicarnasso M, Morgenstern DA, Himoudi N, Pearson K, Anderson J, Thrasher AJ, et al: Polyphenon [corrected] E enhances the antitumor immune response in neuroblastoma by inactivating myeloid suppressor cells. Clin Cancer Res 19: 1116-1125, 2013.

131. Serafini P, Meckel K, Kelso M, Noonan K, Califano J, Koch W, Dolcetti L, Bronte V and Borrello I: Phosphodiesterase-5 inhibition augments endogenous antitumor immunity by reducing myeloid-derived suppressor cell function. J Exp Med 203: 2691-2702, 2006

132. Melani C, Sangaletti S, Barazzetta FM, WerbZ Zand Colombo MP: Amino-biphosphonate-mediated MMP-9 inhibition breaks the tumor-bone marrow axis responsible for myeloid-derived suppressor cell expansion and macrophage infiltration in tumor stroma. Cancer Res 67: 11438-11446, 2007.

133. Valenti R, Huber V, Filipazzi P, Pilla L, Sovena G, Villa A, Corbelli A, Fais S, Parmiani G and Rivoltini L: Human tumor-released microvesicles promote the differentiation of myeloid cells with transforming growth factor- $\beta$-mediated suppressive activity on T lymphocytes. Cancer Res 66 : 9290-9298, 2006

134. Ghoreschi K, Laurence A and O'Shea JJ: Selectivity and therapeutic inhibition of kinases: to be or not to be? Nat Immunol 10 356-360, 2009.

135.Egberts F, Kahler KC, Livingstone E and Hauschild A: Metastatic melanoma: scientific rationale for sorafenib treatment and clinical results. Onkologie 31: 398-403, 2008

136. Motzer RJ, Michaelson MD, Redman BG, Hudes GR, Wilding G, Figlin RA, Ginsberg MS, Kim ST, Baum CM, DePrimo SE, et al: Activity of SU11248, a multitargeted inhibitor of vascular endothelial growth factor receptor and platelet-derived growth factor receptor, in patients with metastatic renal cell carcinoma. J Clin Oncol 24: 16-24, 2006

137. Motzer RJ, Rini BI, Bukowski RM, Curti BD, George DJ, Hudes GR, Redman BG, Margolin KA, Merchan JR, Wilding G, et al: Sunitinib in patients with metastatic renal cell carcinoma. JAMA 295: 2516-2524, 2006

138. Motzer RJ and Bukowski RM: Targeted therapy for metastatic renal cell carcinoma. J Clin Oncol 24: 5601-5608, 2006.

139. Ozao-Choy J, Ma G, Kao J, Wang GX, Meseck M, Sung M, Schwartz M, Divino CM, Pan PY and Chen SH: The novel role of tyrosine kinase inhibitor in the reversal of immune suppression and modulation of tumor microenvironment for immune-based cancer therapies. Cancer Res 69: 2514-2522, 2009.

140. van Cruijsen H, Hoekman K, Stam AG, van den Eertwegh AJ, Kuenen BC, Scheper RJ, Giaccone G and de Gruijl TD Defective differentiation of myeloid and plasmacytoid dendritic cells in advanced cancer patients is not normalized by tyrosine kinase inhibition of the vascular endothelial growth factor receptor. Clin Dev Immunol 2007: 17315, 2007.

141. Xin H, Zhang C, Herrmann A, Du Y, Figlin R and $\mathrm{Yu} \mathrm{H}$ : Sunitinib inhibition of Stat 3 induces renal cell carcinoma tumor cell apoptosis and reduces immunosuppressive cells. Cancer Res 69: 2506-2513, 2009.
142. Bose A, Taylor JL, Alber S, Watkins SC, Garcia JA, Rini BI, Ko JS, Cohen PA, Finke JH and Storkus WJ: Sunitinib facilitates the activation and recruitment of therapeutic anti-tumor immunity in concert with specific vaccination. Int J Cancer 129: 2158-2170, 2011.

143. North RJ: Down-regulation of the antitumor immune response. Adv Cancer Res 45: 1-43, 1985.

144. Hart KM, Usherwood EJ and Berwin BL: CX3CR1 delineates temporally and functionally distinct subsets of myeloid-derived suppressor cells in a mouse model of ovarian cancer. Immunol Cell Biol 92: 499-508, 2014

145. Huang B, Pan PY, Li Q, Sato AI, Levy DE, Bromberg J, Divino $\mathrm{CM}$ and Chen SH: Gr- $1^{+} \mathrm{CD} 115^{+}$immature myeloid suppressor cells mediate the development of tumor-induced $\mathrm{T}$ regulatory cells and T-cell anergy in tumor-bearing host. Cancer Res 66: 1123-1131, 2006.

146. Tomihara K, Guo M, Shin T, Sun X, Ludwig SM, Brumlik MJ, Zhang B, Curiel TJ and Shin T: Antigen-specific immunity and cross-priming by epithelial ovarian carcinoma-induced CD11b(+)Gr-1(+) cells. J Immunol 184: 6151-6160, 2010.

147. Ko HJ, Lee JM, Kim YJ, Kim YS, Lee KA and Kang CY: Immunosuppressive myeloid-derived suppressor cells can be converted into immunogenic APCs with the help of activated NKT cells: an alternative cell-based antitumor vaccine. J Immunol 182: 1818-1828, 2009.

148. Nausch N, Galani IE, Schlecker E and Cerwenka A: Mononuclear myeloid-derived 'suppressor' cells express RAE-1 and activate natural killer cells. Blood 112: 4080-4089, 2008.

149.Greifenberg V, Ribechini E, Rössner S and Lutz MB: Myeloid-derived suppressor cell activation by combined LPS and IFN- $\gamma$ treatment impairs DC development. Eur J Immunol 39: 2865-2876, 2009.

150. Dolcetti L, Peranzoni E, Ugel S, Marigo I, Fernandez Gomez A, Mesa C, Geilich M, Winkels G, Traggiai E, Casati A, et al: Hierarchy of immunosuppressive strength among myeloid-derived suppressor cell subsets is determined by GM-CSF. Eur J Immunol 40: 22-35, 2010.

151. Bronte V: Myeloid-derived suppressor cells in inflammation: uncovering cell subsets with enhanced immunosuppressive functions. Eur J Immunol 39: 2670-2672, 2009.

152. Lioubin MN, Algate PA, Tsai S, Carlberg K, Aebersold A and Rohrschneider LR: p150Ship, a signal transduction molecule with inositol polyphosphate-5-phosphatase activity. Genes Dev 10: 1084-1095, 1996.

153. Helgason CD, Damen JE, Rosten P, Grewal R, Sorensen P, Chappel SM, Borowski A, Jirik F, Krystal G and Humphries RK: Targeted disruption of SHIP leads to hemopoietic perturbations, lung pathology, and a shortened life span. Genes Dev 12: 1610-1620, 1998.

154. Rauh MJ, Ho V, Pereira C, Sham A, Sly LM, Lam V, Huxham L, Minchinton AI, Mui A and Krystal G: SHIP represses the generation of alternatively activated macrophages. Immunity 23 : 361-374, 2005.

155. Paraiso KHT, Ghansah T, Costello A, Engelman RW and Kerr WG: Induced SHIP deficiency expands myeloid regulatory cells and abrogates graft-versus-host disease. J Immunol 178: 2893-2900, 2007.

156. Guedez L, Jensen-Taubman S, Bourboulia D, Kwityn CJ, Wei B, Caterina J and Stetler-Stevenson WG: TIMP-2 targets tumor-associated myeloid suppressor cells with effects in cancer immune dysfunction and angiogenesis. J Immunother 35: $502-512,2012$

157. Kaimala S, Mohamed YA, Nader N, Issac J, Elkord E, Chouaib S, Fernandez-Cabezudo MJ and Al-Ramadi BK: Salmonella-mediated tumor regression involves targeting of tumor myeloid suppressor cells causing a shift to M1-like phenotype and reduction in suppressive capacity. Cancer Immunol Immunother 63: 587-599, 2014 